\title{
Demography, Perceived Risks, Desired Benefits, And Saving Behavior Of Thai Consumers
}

Santi Termprasertsakul, Srinakharinwirot University, Thailand Panid Kulsiri, Srinakharinwirot University, Thailand

\begin{abstract}
This study aims to explore the associations between the saving behavior of Thai individuals and variables, including demography, perceived risks, and desired benefits. The sample composed of 167 individuals in Bangkok. The data were collected by utilizing self-administered questionnaires in a survey. The findings demonstrate that most of the respondents chose to save in terms of depositing money with banks followed by self cash keeping. The saving behavior is associated with demographic variables (except gender) and the perception of saving instrument risks. The desired benefits in terms of profit making had association with the saving behavior.
\end{abstract}

Keywords: Saving methods selection, Demography, Perceived risks, Desired benefits

\section{INTRODUCTION}

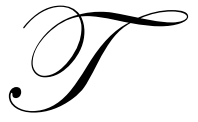

his research aims to focus empirically on the saving behavior of individuals. Empirical research on the savings behavior of consumers has been conducted since the 1950s. However, much of the research was conducted using aggregate rather than individual data (Mirer, 1994). Moreover, most of the studies emphasized only on the explanation of the retirement savings. There is little literature that focuses on the saving behavior of working-age individuals.

It is important to look at things from the consumer's perspective. Marketers should emphasize more in terms of what benefits consumers buy and how they perceive products. Financial products are intangible. Because of the intangible nature of services, it is difficult for a service organization to understand how its customers perceive and evaluate the quality of its services (Parasuraman et al., 1985; Zeithaml, 1981).

\section{LITERATURE REVIEW}

\section{Savings Behavior}

Modigliani and Brumberg (1954) presented one of the most important economic theories regarding saving is the life cycle hypothesis. According to this theory, individuals save some of their earnings to provide for purchases in the final stages of life when they will no longer be earning an income. So in economic terms, saving has been defined as the object of intense theoretical and empirical consideration (i.e. Keynes's Modigliani's, Friedman's and Duesenberry's theories). Also, the buying of shares is clearly a form of saving, an alternative to keeping money in a bank account. Speculating on stock market price movements: seeking to buy and sell at optimal prices, however, resembles a rather familiar practice amongst shoppers, namely bargain hunting (Wilska, 2002). Whereas some researchers (Alhabeeb (1996, 1999); Doss, Marlowe, and Goodwin (1995); Meeks (1998)) also defined "saving" as another category of expenditure.

From a psychological point of views "saving" is defined as a result of a deliberate decision making process and to save as the act of regularly putting away some resources for a goal, such as a pension fund, to buy something, 
or to give a present (Lewis, Webley, and Furnham (1995); Warneryd (1999)). Furnham (1999) provided some indication of why children save and the goals for their saving behavior were only broadly defined, such as "for something special I want to buy," "simply to have more money," "for emergencies," and the like.

Households save for a variety of reasons to save such as retirement, emergencies, down payments, etc. Each particular objective requires a saving instrument with a certain bundle of liquidity, risk, and return. Young households saving for retirement should save in relatively illiquid assets with high returns over the long term, such as mutual funds, retirement funds, housing, or securities. Households saving for emergencies should save in liquid assets with low risk, such as cash deposits (Pootrakool, Ariyapruchya, and Sodsrichai, 2005). Miller (1998) suggests that the elderly rarely save for any particular object that might later improve their standard of living, or even for the feeling of security. It is nevertheless very common for even very poor elderly people to save for their descendants, whether with the aim of purchasing attention and time, or without any expectations of reciprocal acts by the succeeding generations.

People may be motivated to save in order to leave an inheritance to their children because they care about their well-being (Barro, 1974, Hurd 1990). The elderly may save in anticipation of higher medical expenses in their later years, but also as a precaution against the uncertainty of health status and medical expenses (Palumbo, 1999). Some theoretical research claims that precautionary saving may account for most of the saving among young workers for whom earnings are low and retirement distant. Precautionary motive is one of the key reasons people save. Individuals may save to protect themselves against uncertain events, such as the loss of a job, a cut in pay, or medical expenses.

\section{Demographic factors}

Consumer demographics are important for marketers because consumers can be targeted. Consumer behavior differs with demographic variables (Evans et al., 2008). Corresponding to demographic factors, Furnham (1999) examined the relationship between the saving patterns of young people and what he termed the three "classic demographic variables" i.e. age, sex, and social class. He detected numerous differences in economic behavior by sex and age, but his findings indicated that there are few differences across social classes. Men and women tend to have different attitudinal and behavioral orientations, based partly on genetic makeup and partly on socialization (Kotler, 2003). Davies and Lea (1995) found females to be less comfortable with debt and better money managers. Hence, it was predicted that they would save more and borrow less than males.

\section{Risk and Benefits}

Households are faced not only with the question of how much to save, but also how to save. The question of how to save arises because households save for a variety of reasons, such as retirement, emergencies, down payments, etc. Each particular objective requires a saving instrument with a certain bundle of liquidity, risk and return (Pootrakool, Ariyapruchya, and Sodsrichai, 2005). Palumbo (1999) suggests that the uncertainty of future health expenses alone induces a typical family to spend less. The precautionary saving motives arising from future health uncertainty play crucial roles in explaining the observed pattern of individual consumption-saving behavior over a life cycle.

Consumers often think about products in terms of their consequences (Levitt, 1960). Consequences are the outcomes that occur when the product is purchased and used or consumed. Consumers can think about the positive and negative consequences of product use as possible benefits or potential risks. Benefits are the desirable consequences consumers seek when buying products. Perceived risks concern the undesirable consequences that consumers want to avoid when they buy and use products. Consumers are unlikely to purchase products with high perceived risk (Peter and Olson, 2008). If the perceived risk of the product is low, it is more likely to be adopted (Evans et al., 2008).

Pindyck and Rubinfeld (1992) explained that people must choose the amount of risk they wish to bear. People differ in their willingness to bear risk. Some are risk averse, some risk loving, and some risk neutral. A person who is risk neutral is indifferent between earning a certain and an uncertain income but with the same 
expected income. A person who is risk averse prefers a certain given income to a risky job with the same expected income. The vast number of risks that people insure against indicates that most people are risk averse most of the time. One common way consumers reduce risks is diversification. The demand for an asset depends not just on its expected return, but also on its risk. Moreover, Pindyck and Rubinfeld (1992) also explained that an asset is something that provides a monetary flow to its owner. The monetary flow that one receives from owning an asset can take the form of an explicit payment, such as dividend on shares of common stock. The monetary flow from ownership of an asset sometimes is implicit. It takes the form of an increase or decrease in the price or value of the asset. A risky asset provides a monetary flow that is not known with certainty in advance. A risk free asset pays a monetary flow that is known with certainty, such as bonds, passbook savings accounts in a bank and short-term certificates of deposit. Households saving for emergencies should save in liquid assets with low risk, such as cash deposits.

There are many articles showing that the benefits of savings are also linked to individual motives. Keynes (1936) identified eight different themes of saving motives: (1) "Precaution", which implies building up a reserve against unforeseen contingencies; (2) "Foresight", which includes providing for anticipated future differences between income and expenditure; (3) "Calculation", which refers to the wish to earn interest; (4) "Improvement", which means to enjoy a gradually improving standard of living over time; (5) "Independence", which refers to the need to feel independent and to have the power to do things; (6) "Enterprise", which means having the freedom to invest money if and when it is favorable; (7) "Pride", which concerns leaving money to heirs (the bequest motive); and (8) "Avarice" or pure miserliness. Lindqvist (1981) has proposed a structure of reasons for saving in which at the lowest level is the need to handle cash to deal with short-term financial goals and the second level the need to have a reserve of money as a precautionary measure. At the third level is the need to have a large amount of money to buy something expensive and finally at the top level there is the need to manage accumulated wealth.

Wärneryd (1995) distinguished four motives for saving and stressed that a person can save for one or more motives at the same time. Wärneryd labels the first "Saving as a continuous habit". This is a well established habit of saving which is not related to any specific goal. The second, the so-called "precautionary motive", is due to uncertainty about the future. The third motive for saving is the "Bequest motive", which is saving for the well being of the family after the person's death. The forth and last motive is called the "Profit motive" and consists of the wish to make an income from money put aside. Canova, Rattazzi, and Webley (2005) divided the hierarchical structure of saving motives into three positions. At the bottom of the hierarchy are more concrete goals ("Purchase", "Holidays" or "Money Availability") while at the top are more abstract goals ("Self - esteem", "Self gratification"). In the intermediate position are goals which channel the more concrete towards the more abstract.

From the idea of saving motives, Katona (1975) showed that in the United States in the 1960s, people saved, in order, for emergencies (ill - health, unemployment), to have funds in reserve for necessities, for retirement or old age, for their children's needs, to buy a house or durable goods, and for holidays. Few claimed to save to earn future income (in the form of interest or dividends) or to leave money to their heirs. Moreover, Kotlikoff (1989) revealed that about $30 \%$ of family savings in the United States can be explained by motives of a precautionary nature, in particular by anxieties of old age.

\section{METHODS}

\section{Data and Sample}

The sample for the study consisted of 167 respondents in Bangkok. The response rate was $67 \%$. The data were collected by the survey method. The self-administered questionnaires were utilized to collect data.

\section{Variables}

\section{Dependent variable}

In this paper, saving refers to preserving money for future use. The dependent variable is saving behavior which refers to the saving methods selection that the individuals put most of their money in for future use. These 
methods include self cash-keeping, holding bank savings account or buying bonds, investing in mutual funds or purchasing stocks, and buying real assets, such as jewelry and real estate.

\section{Independent variables}

The independent variables include demography, perceived risks, and desired benefits. The demography includes gender, age, marital status, employment status, education attainment, monthly income, and number of dependants, public medical care program membership, company's health insurance provision, and spending behavior. Age was measured through a categorical variable with groupings of -24, 26-30, 31-35, and 36 and over. Marital status was classified as single and married. Employment was measured in terms of employed and unemployed. Education attainment was divided into groups of non-college degree and college degree. Monthly income was measured with groupings of not over 10,000 baht, 10,001-20,000 baht, 20,001-30,000 baht, and 30,001 baht and over. One US dollar approximately equals 33 baht. Number of dependants ranged from one to four members, including the respondent. The spending behavior was measured in terms of spending more than monthly income, spending less than monthly income and balanced spending.

The perceived risks are categorized as perceived personal risks and perceived saving instrumental risks. The perceived personal risks are measured in terms of high or low health risk, information risk, and occupational risk. The health risk refers to the risk of unanticipated sickness and increases of medical expenses. The information risk refers to the risk from lacking knowledge of appropriate saving methods, money devaluation, and financial illiquidity. The occupational risk refers to the uncertainty of monthly income and job tenure.

The perceived saving instrumental risks are measured in terms of high or low level of risks from the utilization of saving instruments. The saving instruments include interest-bearing assets, investment-based assets, and speculative real assets. The risks of interest-bearing assets contain the risk of depositing money with banks and purchasing bonds. The risks of investment-based assets contain the risk of mutual funds investment, purchasing cooperatives' shares, and purchasing stocks. The risks of speculative real assets contain the risk of purchasing Government Savings Bank's lottery and purchasing jewelries and real estates.

The desired benefit refers to the advantage that individuals achieve from saving. These benefits include tax reduction or tax avoidance; profits in terms of interest, dividend, or price differences; risk-free saving; saving for emergencies; and bequest motive.

\section{Analyses}

Responses were analyzed by using SPSS software. Chi-square tests were conducted to test the hypotheses of the associations between saving behavior and independent variables including demographic variables, perceived personal risk, perceived risks of the saving instruments, and desired benefits from saving. Significance was tested at the 0.05 level.

\section{RESULTS}

\section{Saving Behavior}

The study of the saving behavior of 167 respondents found that $52 \%$ of the respondents deposited their money with banks, 37\% kept cash with them, eight percent invested in mutual funds, and three percent purchased real assets.

\section{Demographic Characteristics}

The sample composed of $23 \%$ male and $77 \%$ female respondents. Of those participating, $38.3 \%$ were in the age group of $21-25,85.5 \%$ were single, $68.5 \%$ were employed, $69.5 \%$ had college degrees, $36 \%$ earned not over 10,000 baht per month, $59.5 \%$ were self dependent, $61.5 \%$ were not public medical care program members, $61.5 \%$ had company's medical welfare, and $41.5 \%$ were balanced spenders. 
In the study of saving behavior in terms of the saving methods selection, it was found that most of the respondents who selected to keep cash with them instead of other saving methods are those who were in the age group of 21-25, unemployed, had non-college education, monthly earned not over 10,000 baht, self dependent, without company's medical welfare provision, and spent more than monthly income. Most of the respondents who select to deposit money with banks were both male and female, either married or single, in the age group of 26 and over, employed, had a college degree, earned more than 10,000 baht per month, had dependants, either with or without public medical care program membership, had company's medical welfare provision, and either balanced their expenses with their income or spent less than their income.

The Chi-square tests indicated that age, marital status, employment, education attainment, monthly income, number of dependants, public medical care program membership, company medical welfare provision, and spending behavior significantly associated with saving behavior in terms of saving method selection.

\section{Perceived Personal Risks}

The study found that most of the respondents perceived that they had high health risk but had low informational and occupational risks. In addition, most of the respondents either in the groups of low or high risks perception, in terms of these three risks, selected to deposit money with banks more than other saving methods. The Chi-square tests do not support the hypotheses of the associations between the perceived personal risks and the saving behavior.

\section{Perceived Saving Instruments Risks}

The study found that most of the respondents perceived that interest-bearing assets and speculative real assets had low risks whereas investment-based assets had high risks. Most of the respondents who perceived that interest-bearing assets had high risk selected to keep cash with them instead of utilizing other saving instruments. In the meantime, most of the respondents who perceived that interest-bearing assets had low risk deposited their money with banks. In addition, most of the respondents either perceived the speculative real assets and investment-based assets as having high or low risks indifferently deposited money with banks more than utilizing other saving instruments. The Chi-square tests supported only the hypothesis of the association between the perceived risks of the investment-based assets and the saving methods selection.

\section{Desired Benefits}

The study found that most of the respondents had low desires to utilize the saving instruments for tax reduction or tax avoidance. Most of them had high desires to utilize the saving instruments for making profits, riskfree saving, emergencies, and accumulating bequests. The study indicated that most of the respondents either had high or low desires to have advantage of saving in terms of tax reduction, making profits, risk-free saving, or accumulating bequests selected to deposit most of their savings with banks. For the respondents who had high desire to save for emergency will likewise deposit money with banks but those who had this desire at the low level selected to keep money with them more than utilizing other saving methods. The Chi-square tests supported only the hypothesis of the association between the making profits motive and the saving behavior.

\section{DISCUSSION}

This research paper shows that all of demographic variables, except gender, support the hypotheses of the association with saving behavior in terms of saving method selection. It means that there is no difference in the way men and women save. The significant differences in saving behavior when the respondents were classified in terms of other demographic variables provide us to set the marketing strategy for bank or financial institution products. For example, the result shows that most of the respondents who monthly earned not over 10,000 baht (approximately 310 USD) decided to keep cash with them instead of other saving method. Bank or financial institution should create new saving products that are suitable for them in terms of amount to save and saving horizon. 
In terms of perceived personal risk, the hypothesis on its association with saving behavior is not supported. It means Thai savers do not consider their health risk, informational risk, and occupational risk in their saving method selection. However, Thai savers significantly aware of the perceived saving instrument risks before they decided to save. The data show that the higher risk the saving instruments (such as mutual funds investment, purchasing cooperatives' shares, and purchasing stocks) are, the more conscious they consider how to save. These results are supported by the concept of risk aversion, investors do not like risk. Therefore, the investors will carefully invest in high risk financial instruments. Moreover, Peter \& Olson (2008) and Evans et al. (2008) also suggested that consumers are unlikely to purchase products with high perceived risk. On the contrary, if the perceived risk of the product is low, it is more likely to be adopted.

The desired benefits, especially, profits in terms of interest, dividend, or price differences, supported the hypothesis of the association with saving behavior. This result indicates that Thai savers have the motivation to save only for cash or amount of money. Likewise Keynes (1936), Linqvist (1981) and Warneryd (1995) argued that cash or amount of money were individual motives and primary motives to save. However, the advantage of saving in terms of tax reduction, risk-free saving, or accumulating bequests does not support the hypotheses of their association with saving behavior. It means that Thai savers do not recognize these motivations. It might due to the fact that most of the respondents were in the age group of 21-25 and monthly earned less than 10,000. This group of respondents was young and were new workers with low experience. They have many saving limitations, such as the amount of money to save or the saving alternatives. Thus, the desired benefits of Thai savers were profit-making only.

\section{CONCLUSIONS}

In this research, our aim is to focus empirically on the saving behavior of Thai individuals. We find that Thai savers prefer to deposit their money with bank to other saving method selection. In terms of perceived risk, Thai savers significantly aware of the perceived saving instrument risks rather than the perceived personal risk. Also, the motivation of Thai savers is to make a profit such, as interest, dividend, or capital gain. This result enhances our better understanding about Thai individuals' saving behavior in terms of saving methods selection. Still, there are many aspects of saving behavior and its antecedents that we have not studied. For further study, we suggest that the researchers could strengthen the other saving behaviors by collecting the data such as the proportion of money to save, the decision to save in financial products or non-financial products or spending/ consumption behaviors. Furthermore, researchers should more focus on independent variables in terms of work experiences or the attention of saving method information. These additional variables will clearly help banks and financial institutions to create new financial products for Thai savers and to enhance the motivation of Thai individuals to save.

\section{AUTHOR INFORMATION}

Santi Termprasertsakul is a lecturer in the School of Business Administration at Srinakharinwirot University, Thailand. He teaches International Finance, Financial Derivatives, and Business Finance. His research primarily focuses on financial model. He holds a bachelor degree in business administration specializing in finance and banking from Thammasat University and MBA in finance from National Institute of Development and Administration.

Panid Kulsiri is an academic in the School of Business Administration at Srinakharinwirot University, Thailand. She teaches marketing, strategic management, management theories, and marketing research. Her research primarily focuses on consumer behavior and marketing mix factors. She has translated many books in the field of public relations. She holds a B.A. in English from Silpakorn University, an MBA in international business from University of Thai Chamber of Commerce, an M.A. in business English for international communication from Srinakharinwirot University, and an M.A. in development communication and a DBA in international business from Chulalongkorn University. 


\section{REFERENCES}

1. Alhabeeb, M. J. (1996). Teenagers' money, discretionary spending and saving. Financial Counseling and Planning Journal, 7, 123 - 132.

2. Alhabeeb, M. J. (1999). Teen's consumption patterns: The impact of employment status and intensity. Academy of Marketing Studies Journal, 3(1), 45 - 57.

3. Anderson, C. L. \& Nevitte, N. (2006). Teach your children well: Values of thrift and saving. Journal of Economic Psychology, 27, $247-261$.

4. Barro, R. J. (1974). Are Government Bonds Net Wealth?, Journal of Political Economy, November/ December, 82(6), 1095-1117.

5. Browning, M. \& Lusardi, A. (1996). Household Saving: Micro Theories and Micro Facts, Journal of Economic Literature, American Economic Association, vol. 34(4), December, 1797-1855.

6. Canova, L., Rattazzi, A. M. M., \& Webley P.. (2005). The hierarchical structure of saving motives. Journal of Economic Psychology 26, 21 - 34.

7. Carroll, C. D. (1997). Buffer-Stock Saving and the Life Cycle/Permanent Income Hypothesis. Quarterly Journal of Economics, vol. 112, no. 1 (February 1997), 1-55.

8. David, M. (1998). A Theory of Shopping. Cambridge: Polity Press.

9. Davies, E., \& Lea, S. (1995). Student attitudes to student debt. Journal of Economic Psychology, 10, 663 679.

10. Doss, V.S., Marlowe, J., \& Goodwin, D.D. (1995). Middle - school children's sources and use of money. Journal of Consumer Affairs, 29(1), 219 - 241.

11. Evans, Martin, Ahmad Jamal, and Gordon Foxall. (2008). Consumer Behavior.

12. Fisher, I. (1930). The theory of interest. New York: Macmillan.

13. Furnham, A. (1999). The saving and spending habits of young people. Journal of Economic Psychology, 20(6), $677-697$.

14. Hurd, M. (1990). Research on the Elderly: Economic Status, Retirement, and Consumption and Saving. Journal of Economic Literature 28, 565-637.

15. Katona, G. (1975). Psychological economics. New York: Elsevier.

16. Keynes, J. M. (1936). The general theory of employment, interest and money. London: Macmillan.

17. Kotler, P. (2003). Marketing Management, New Jersey: Prentice Hall.

18. Kotlikoff, L. J. (1989). What determines savings? Cambridge, MA: The MIT Press.

19. Lewis, A., Webley, P., \& Furnham, A. (1995). The new economic mind. The social psychology of economic behavior. Hemel Hempstead, UK: Harvester Wheatsheaf.

20. Lindqvist, A. (1981). Hushållens sparande [The Saving Behavior of Households]. Doctoral dissertation, The Stockholm School of Economics, Stockholm.

21. Meeks, C.B. (1998). Factors influencing adolescents' income and expenditures. Journal of Family and Economic Issues, 19(2), 131 - 150.

22. Modigliani, F., \& Brumberg, R. (1954). Utility analysis and the consumption function. An interpretation of cross - section data. In K. K. Kurihara (Ed.), Post-Keynesian economics. New Brunswick, NJ: Rutgers University Press.

23. Palumbo, M. G. (1999). Uncertain Medical Expenses and Precautionary Saving Near the End of the Life Cycle. Review of Economic Studies, April, 66(2), 395-421.

24. Peter, J. Paul and Jerry C. Olson. (2008). Consumer Behavior and Marketing Strategy.

25. Pindyck, R. S. \& Rubinfeld, D. L.. (1992). Microeconomics. New York: Macmillan Publishing Company.

26. Pootrakool, K., Ariyapruchya, K., \& Sodsrichai, T. (2005). Long-Term Saving in Thailand: Are We Saving enough and What are the risks?

27. Thad, M. (1994). The Dissaving of Annuity Wealth and Marketable Wealth in Retirement. Review of Income and Wealth, March, 40(1), 87-97.

28. Wärneryd, K. (1995). A study of saving behavior towards the end of the life cycle. Center for Economic Research, Tillburg University, Progress Report No. 28.

29. Wärneryd, K. (1999). The psychology of saving - a study in economic psychology. UK: Edgar Elgar. 
NOTES 